\title{
Digestion of a dehydrated lucerne/barley diet (70:30) in defaunated, Isotricha-monoinoculated and mixed-fauna-inoculated rumen in sheep
}

\author{
J Sénaud 1, JP Jouany 2, B Lassalas 2, J Bohatier 1,3 \\ 1 Université Blaise-Pascal, laboratoire de protistologie, URA CNRS 1944, \\ complexe scientifique des Cézeaux, 63177 Aubière cedex; \\ 2 INRA, unité de la digestion microbienne, centre de recherches de Clermont-Theix, \\ 63122 Saint-Genès-Champanelle; \\ 3 Université d'Auvergne, faculté de pharmacie, laboratoire de biologie cellulaire, \\ 63001 Clermont-Ferrand, France
}

(Received 14 November 1994; accepted 6 February 1995)

\begin{abstract}
Summary - Two adult Texel sheep fitted with permanent rumen fistulae were defaunated for 12 weeks in a preliminary experiment. They were then reinoculated with Isotricha sp for 11 weeks, and finally with a mixed fauna (Entodinium, Epidinium, Eudiplodinium and /sotricha) for 10 weeks. They were fed a diet composed of dehydrated lucerne $(700 \mathrm{~g} / \mathrm{d})$, pelleted barley grain $(300 \mathrm{~g} / \mathrm{d})$, grass hay $(100 \mathrm{~g} / \mathrm{d})$ and wheat straw $(50 \mathrm{~g} / \mathrm{d})$ in one daily meal. Isotricha and the ciliates of the mixed fauna developed rapidly, reaching a maximum concentration 9-17 d after inoculation. Their concentration then fell for 2-3 d and finally stabilized at values close to $104 / \mathrm{ml}$ for $/$ sotricha, Eudiplodinium and Epidinium and $2.5 \times 10^{5} / \mathrm{ml}$ for Entodinium. The estimated ciliate biomass in the rumen was $1.8 \mathrm{~g} \mathrm{I}^{-1}$ for a volume of $10.2 \mathrm{ml} \mathrm{l}^{-1}$ in the Isotricha-monoinoculated sheep and $4.7 \mathrm{~g} \mathrm{l}^{-1}$ for a volume of $25.0 \mathrm{ml} \mathrm{l}^{-1}$ in mixedfauna-inoculated sheep. The concentration of Isotricha was unaffected by the inoculation of mixed fauna during the third part of the experiment. No difference in total rumen bacteria counts was observed between defaunated, monoinoculated and completely refaunated animals. The total adenylic nucleotide concentration in filtered rumen juice was 4 times higher in faunated sheep just before feeding and 4-9 times lower after feed intake as compared to defaunated animals; the energy charge was always higher in faunated animals. These results are discussed in relation to the digestive activity and biomass of the protozoa. The in situ degradation of lucerne stems was the highest in the mixed-faunated sheep over a retention time interval of $6-18 \mathrm{~h}$. The values obtained in isotricha-monoinoculated sheep were intermediate between the defaunated and the mixed-faunated states. The digestibility in the whole digestive tract of dietary dry matter, organic matter, nitrogen and neutral detergent fibre was unaffected by the addition of either Isotricha or the mixed fauna in defaunated rumens. The total volatile fatty acid concentration was higher $(p<0.05)$ in the defaunated sheep between 6 and $18 \mathrm{~h}$ after feeding. The molar proportion of butyrate was significantly $(p<0.05)$ increased by the presence of mixed fauna in the rumen while that of propionate and valerate was lower. A non-significant decrease in acetate was also observed. The concentration of $\mathrm{NH}_{3}-\mathrm{N}$ in the rumen was significantly increased
\end{abstract}


$(p<0.05)$ by the presence of the mixed fauna in the rumen but was unaffected or slightly reduced by Isotricha alone. This result is discussed in relation to nitrogen utilization in ruminants.

rumen / protozoa / digestion / defaunation / Isotricha

Résumé - Digestion d'une ration composée de luzerne déshydratée et d'orge (70:30) chez des moutons défaunés, monoinoculés avec Isotricha et inoculés avec une faune mixte. Deux moutons adultes de race Texel, munis de fistules permanentes du rumen, ont été défaunés pendant la première période, puis inoculés avec Isotricha sp pendant la seconde période, et finalement avec une faune mixte composée dEntodinium, Epidinium, Eudiplodinium, Isotricha pour la $3^{e}$ période. Ils ont reçu une ration composée de luzerne déshydratée ( $700 \mathrm{~g} / \mathrm{j})$, d'orge, de foin de Graminées (100 g/j) et de paille de blé $(50 \mathrm{~g} / \mathrm{j})$ en un seul repas par jour. Isotricha et les ciliés de la faune mixte se sont développés rapidement, atteignant un maximum 9-17 j après leur inoculation. Leur concentration a ensuite baissé pendant 2 à $3 j$ et s'est finalement stabilisée à des valeurs proches de $10^{4} / \mathrm{ml}$ pour Isotricha, Eudiplodinium et Epidinium et 2,5 $\times 105 / \mathrm{m} /$ pour Entodinium. La biomasse des ciliés était de $1,8 \mathrm{~g}^{-1}$ pour un volume de 10,2 $\mathrm{ml}^{-1}$ chez les animaux monoinoculés avec Isotricha et $4,7 \mathrm{~g}^{-1}$ pour un volume de 25,0 $\mathrm{m} / \mathrm{t}^{+1}$ chez les animaux à faune mixte. La concentration d'sotricha n'a pas été modifiée par l'introduction de la faune mixte au cours de la $3^{e}$ période. II n'y a pas eu de différence dans la concentration des bactéries totales entre les 3 périodes. Comparée à celle des animaux défaunés, la concentration en nucléotides adényliques totaux dans le jus de rumen filtré grossièrement était 4 fois plus élevée chez les animaux faunés juste avant le repas et 4 à 9 fois plus faible après le repas. La charge énergétique était toujours plus élevée chez les animaux faunés. Ces résultats sont discutés en relation avec l'activité digestive et la biomasse des protozoaires. La dégradation in situ des tiges de luzerne était plus élevée chez les animaux faunés dans l'intervalle du temps de séjour de 6 à $18 \mathrm{~h}$. Les valeurs obtenues chez les animaux inoculés par Isotricha étaient intermédiaires entre celles mesurées chez les animaux défaunés et les animaux à faune mixte. La digestibilité de la MS, MO, N, NDF n'a pas été affectée par l'addition des ciliés chez les animaux défaunés. La concentration en AGV totale était supérieure $(\mathrm{P}<0,05)$ chez les animaux défaunés entre 6 et $18 \mathrm{~h}$ après le début du repas. La proportion molaire de butyrate était significativement $(\mathrm{P}<0,05)$ accrue par la présence d'une faune mixte dans le rumen tandis que celle du propionate et du valérate était plus faible. Une diminution non significative de l'acétate a été observée chez les mêmes animaux. La concentration en $\mathrm{N}-\mathrm{NH}_{3}$ dans le rumen était significativement augmentée $(P<0,05)$ par la présence d'une faune mixte dans le rumen, mais n'a pas été affectée ou a légèrement diminué chez les animaux monoinoculés avec Isotricha. Ce dernier résultat est discuté en relation avec l'utilisation de l'azote par les Ruminants.

rumen / protozoaires / digestion / défaunation / Isotricha

\section{INTRODUCTION}

Studies carried out over the last 10 years on the effect of protozoa on the rumen metabolism have clearly demonstrated that defaunation increases the flow of both dietary and microbial proteins in the duodenum (Veira et al, 1984; Ushida et al, 1986; Itabashi et al, 1989). However, the effect of protozoa on plant cell-wall degradation is still under debate (Veira, 1986; Punia et al, 1987; Ushida et al, 1987; Ushida et al, 1991). According to Ushida et al (1991), the effect of protozoa on the stimulation of cellwall carbohydrate digestion is enhanced by the addition of large amounts of starch to the diet. In this context, the real impact of protozoa on the other components of the rumen ecosystem (bacteria and fungi) and their energetic state has not been extensively studied as yet.

Most studies on the role of protozoa have compared digestion in conventional animals with that of animals in which the rumen protozoa were first removed (defaunated). The inoculation of the single genera 
Isotricha in previously defaunated sheep represents an interesting intermediate status for study. Bird and Leng $(1978,1984)$ and Bird et al (1979) showed that elimination of fauna from animals fed sugar cane or molasses, which renders the holotrichs dominant in rumen fauna, significantly improved animal performances. Furthermore, Jouany et al (1992) observed in vitro that protein degradation to the $\mathrm{NH}_{3}-\mathrm{N}$ stage decreased by $15-45 \%$ when a mixed fauna was replaced by /sotricha alone in the rumen.

The aim of this study was to determine the effect of /sotricha alone or a mixed fauna on the bacteria population and its metabolic activity. The latter was estimated from measurements of energy charges and the concentration of the end products of fermentation in animals fed 1 daily ration of an energyrich diet that favoured protozoal growth and resulted in unstable rumen conditions $(\mathrm{pH}$, volatile fatty acid (VFA) and $\mathrm{NH}_{3}$ concentrations). The impact of the protozoa of the cellulolytic activity of rumen microbes was measured in situ using a graminae and a legume as substrates. The deaminating activity of rumen microbes is discussed in relation to the $\mathrm{NH}_{3}-\mathrm{N}$ concentration.

\section{MATERIALS AND METHODS}

\section{Animals}

Two adult male Texel sheep weighing $73 \mathrm{~kg}$ (sheep A) and $75 \mathrm{~kg}$ (sheep B) were fitted with wide rumen cannulae ( $75 \mathrm{~mm}$ inside diameter) and used in this study. Their rumen was defaunated for the first experimental period according to the method described by Jouany and Sénaud (1979). Measurements began 6 weeks after completion of the defaunation treatment.

At the end of the first period, $100 \mathrm{ml}$ of rumen content containing $2.5 \times 10^{5}$ Isotricha prostoma was introduced into the rumen. Donor animals monoinoculated with / prostoma had been pre- viously prepared according to the method described by Jouany (1978). The second experimental period started 5 weeks after the Isotricha were established. At the end of this second period an inoculum containing a mixture of the genera Entodinium, Eudiplodinium and Epidinium was withdrawn from 3 different sheep, each of which had been monoinoculated with 1 of the genera, and was introduced into the rumen of the 2 sheep previously monoinoculated with Isotricha. Measurements for the third period began 4 weeks after the mixed ciliate population was stabilized in the rumen.

\section{Feed}

The sheep were fed 1 daily ration composed of $700 \mathrm{~g}$ dehydrated pelleted lucerne, $300 \mathrm{~g}$ pelleted barley gain, $100 \mathrm{~g}$ chopped natural meadow grass hay and $50 \mathrm{~g}$ chopped wheat straw, given as a heterogeneous mixture in a single meal at 9.00 am. Dry matter (DM), organic matter (OM) and nitrogen $(\mathrm{N})$ contents in the total diet were $920 \mathrm{~g} / \mathrm{kg}$ fresh matter, $910 \mathrm{~g} / \mathrm{kg} \mathrm{DM}$ and $24.5 \mathrm{~g} / \mathrm{kg}$ DM respectively. The ration was totally ingested in $20 \mathrm{~min}$. Water and salt licks were available ad libitum.

\section{Measurements}

The ciliates were counted using a Dolfuss cell onto which was placed $0.05 \mathrm{ml}$ of the liquid that was obtained by manually squeezing rumen contents through a metal gauze with a mesh size of $1 \mathrm{~mm}^{2}$. The entire cell was evenly covered with Hungate solution and counting was made through a binocular magnifier ( $x 80)$.

To calculate the volume of ciliates in the rumen, the mean volumes of large (Eudiplodinium, Isotricha), medium (Epidinium, some Entodinia) and small ciliates (small Entodinia) were taken to be $10^{6}, 10^{5}$ and $10^{4} \mu \mathrm{m}^{3}$ respectively (Warner, 1962; Williams and Coleman, 1992). The corresponding biomass was calculated from the estimations of Leng et al (1981) and Broad and Dawson (1975): $17.8 \mathrm{mg} \mathrm{DM} / 10^{5}$ cells for large ciliates; $2.0 \mathrm{mg} \mathrm{DM} / 10^{5}$ cells for medium-sized ciliates; and $0.25 \mathrm{mg} \mathrm{DM} / 10^{5}$ cells for small ciliates.

Plant cell-wall degradation in the rumen was characterized by the in situ technique. Two 
substrates were used, 1 for the cell walls of graminae (the same wheat straw used in the diet), and the other for leguminous cell walls (lucerne stems). Lucerne stems were obtained from lucerne harvested late in dry conditions and were different from the lucerne in the diet. The substrates were ground through a $4 \mathrm{~mm}$ screen; only particles larger than $160 \mu$ were placed in bags after sieving ( $3 \mathrm{~g}$ per bag measuring $5 \times 10 \mathrm{~cm}$ each). These bags were made of woven fabric with a mesh size of $95 \mu$ (Ankon Co, New York, USA). The bags were immersed in water at $39^{\circ} \mathrm{C}$ for $10 \mathrm{~min}$ to eliminate soluble material and physical losses of substrate and to facilitate the passage of microorganisms. They were then placed in the rumen for $6,12,18,24$ and $48 \mathrm{~h}$ for wheat straw, and 3, 6, 12, 18 and $24 \mathrm{~h}$ for lucerne stems. Bags were washed for $5 \mathrm{~min}$ in water at $10^{\circ} \mathrm{C}$ using an electric washing machine. Washing cycles were repeated 4 times, until the water was clear. Bags were then dried at $80^{\circ} \mathrm{C}$ for $48 \mathrm{~h}$. Measurements were repeated to obtain at least 4 values per point per sheep. Neutral detergent fiber (NDF) content of wheat straw and lucerne stems before and after in situ degradation was determined according to Van Soest and Wine (1967).

The in vivo digestibility of the diet was measured by monitoring the amounts ingested and the total faeces collected over a period of at least $7 \mathrm{~d}$.

The $\mathrm{pH}$ and redox potential of the rumen fluid were measured immediately after sampling with a Schott-Geräte CG-817-T pH meter (6238 Hofheim, Germany), fitted with a 1042A electrode for the $\mathrm{pH}$ and a Pt-42-A electrode for the redox potential. The electrode for redox potential was calibrated with a standard solution $(34.3 \mathrm{rH}$ from Bioblock Scientific, France) just before the measurements were taken in an oxygen-free cell as described by Prévot (1990). Redox potential determinations on rumen samples were made rapidly after sampling in the same conditions.

Total VFAs were assayed by gas-liquid chromatography, according to Jouany (1982), on $9 \mathrm{ml}$ samples mixed with $1 \mathrm{ml}$ of $5 \%$ (w/v) orthophosphoric acid and stored at $-20^{\circ} \mathrm{C}$. The samples were taken from the rumen $0,3,6,12$ and $18 \mathrm{~h}$ after feeding.

Ammonia nitrogen $\left(\mathrm{NH}_{3}-\mathrm{N}\right)$ was assayed according to the Van Eenaeme et al (1969) method, with a Technicon autoanalyser in $2 \mathrm{ml}$ of rumen fluid mixed with $8 \mathrm{ml}$ of $12.5 \%(\mathrm{w} / \mathrm{v})$ $\mathrm{NaCl}$. The samples were stored at $-15^{\circ} \mathrm{C}$.
The bacteria were counted after staining with acridine orange. This method is widely used in hydrobiology (Bergström et al, 1986) and was adapted for the rumen by Prévot et al (1988). The bacteria are green when double stranded nucleic acids (DNA) predominante, and red when the single stranded nucleic acids (RNA and denatured DNA) are more abundant. The bacteria from the sample undergoing analysis were collected on microfilters previously treated with Irgalan blue and then mounted on slides. These were then examined through a light microscope for epifluorescence (Prévot, 1990).

The adenylic nucleotides (ATP, ADP, AMP) were extracted by DMSO (Jakubczak and Leclerc, 1981) under cold conditions ( $5 \mathrm{~min}$ at room temperature, then preserved in liquid $\mathrm{N}_{2}$ ) until analysis by bioluminescence using a Lumac Biocounter M 2500 nucleotimeter (Perstorp, Paris, France), with the luciferin-luciferase system extracted from the firefly (buffered dried firefly extract) (Sigma, 38299 Saint-Quentin-Fallavier, France) as described by Strehler and Tötter (1954). The luciferase causes the luciferin to oxidize and thereby emit a number of photons proportional to the quantity of ATP involved in the reaction. The ATP is assayed directly, while the ADP and AMP are converted into ATP by enzyme action before assay. AMP was converted to ADP by adenylate kinase (Myokinase Sigma), and ADP into ATP by pyruvate kinase (SIGMA) according to the following equations (see Pradet, 1967):

$$
\begin{aligned}
& \mathrm{AMP}+\mathrm{ATP} \stackrel{\text { adenylate kinase }\left(\mathrm{Mg}^{2+}\right)}{\longrightarrow} 2 \mathrm{ADP} \\
& \mathrm{ADP}+\text { phosphoenolpyruvate } \\
& \text { pyruvate kinase }\left(\mathrm{Mg}^{2+}, \mathrm{K}^{+}\right)
\end{aligned}
$$

The method was adapted to rumen conditions by Bohatier et al (1992).

The energy charge [EC $=(A T P+1 / 2$ ADP $) /$ (ATP + ADP + AMP)] was proposed by Atkinson and Walton (1967) to characterize the overall physiological state of microorganisms. It is high for microbes in the growth phase and low for those in their stationary or senescent phases (Swedes et al, 1975).

\section{Experimental procedure}

The experiment consisted of 3 main periods: period 1 , the sheep were defaunated; period 2, the sheep 
were refaunated with / prostoma; and period 3 , sheep refaunated with a mixed B-type fauna. Each measurement period, lasting 6 weeks, began after a period of adaptation to the new conditions of the rumen fauna: 6 weeks after defaunation was achieved for adaptation during period $1 ; 5$ weeks after /sotricha became stable for period 2; and 4 weeks after the mixed fauna stabilized for period 3. During each period, the first 2 weeks were used for faeces collection; 2 weeks were then necessary for in sacco determination of lucerne stem and wheat straw digestibilities; and 2 further weeks were necessary to sample rumen contents for metabolic parameters ( $\mathrm{pH}$, VFA, Eh, adenylic nucleotides). Protozoa were counted daily $2 \mathrm{~h}$ after feeding during the establishment of protozoa, and for $16 \mathrm{~d}$ after the protozoa population had stabilized. Bacteria were counted in rumen contents sampled for the measurement of rumen metabolic parameters during the 5th and 6th weeks of each experimental period. The evolution of protozoa populations was followed by sampling rumen juice for 4 successive days at times $0.5,1.5,3$ and $6 \mathrm{~h}$ after feeding the animals.

\section{Statistical analysis}

As the defaunating treatment is drastic, the experimental design had to follow the sequential order of defaunation, refaunation with Isotricha alone and faunation with the mixed fauna. A latin square design was therefore impossible to apply.

Data were analyzed according to the Anova procedure (SAS, 1985) as described by Jouany et al (1995). The model used was as follows: $Y_{i j}=\mu$ $+A_{i}+T_{j}+\ddot{O}_{i j}$, where $Y_{i j}=$ trait observed, $A_{i}=$ animal effect, $T_{j}=$ protozoa effect, $\ddot{O}_{i j}=$ error, assumed to be the effects of the interaction between animal and protozoa.

As mature castrated males were used and maintained in a pen with constant temperature and light between periods, we considered that the time effect was negligible. We assumed that differences between periods were due to protozoa.

\section{RESULTS}

No accidental contamination of the rumen occurred during the experiments. Defaunation was maintained throughout the first period. Isotricha was the only genus present in the rumen throughout the second period, and the ciliate mixture introduced at the beginning of the third period remained unmodified.

\section{Establishment of Isotricha in the defaunated rumens}

After introduction of $2.5 \times 10^{5} /$ prostoma into the rumen of each sheep (corresponding to a mean concentration of 25 cells $/ \mathrm{ml}$ of rumen content), the ciliates were detectable $7 \mathrm{~d}$ later at an average concentration of 5 ciliates $/ \mathrm{ml}$ (fig 1). This implies that a large proportion of the ciliates disappeared after being introduced into the rumen.

As already observed in previous studies (Sénaud et al, 1980; Jouany et al, 1995), the population of Isotricha grew rapidly for $10 \mathrm{~d}$ after being detectable in the rumen (day 7), peaking at $15 \times 10^{3}$ ciliates $/ \mathrm{ml}$ on day 17 after seeding. It then fell for $2 d$ to $6 \times 10^{3}$ ciliates $/ \mathrm{ml}$ and finally stabilized at values close to $10^{4} / \mathrm{ml}$ in both sheep.

\section{Establishment of mixed fauna in rumens containing the genus Isotricha}

After the introduction of $250 \mathrm{ml}$ pooled rumen contents withdrawn from the 3 sheep which had been monoinoculated with either Entodinium, Epidinium or Eudiplodinium all the ciliates were immediately detected in the receptor sheep (fig 2). Entodinium peaked on day $9\left(10^{6} / \mathrm{ml}\right)$, falling off thereafter for $7 \mathrm{~d}\left(1.7 \times 10^{5} / \mathrm{ml}\right)$ before increasing again and levelling off at $3.0 \times 10^{5} / \mathrm{ml}$. Eudiplodinium peaked from days $6-10$ after inoculation $\left(4.0 \times 10^{4} / \mathrm{ml}\right)$, and then fell slightly before settling at $2.5 \times 10^{4} / \mathrm{ml}$. In sheep B, Epidinium increased up to day 13 $\left(2.0 \times 10^{4} / \mathrm{ml}\right)$ and then fell for $3 \mathrm{~d}$ before increasing again and stabilizing at about 


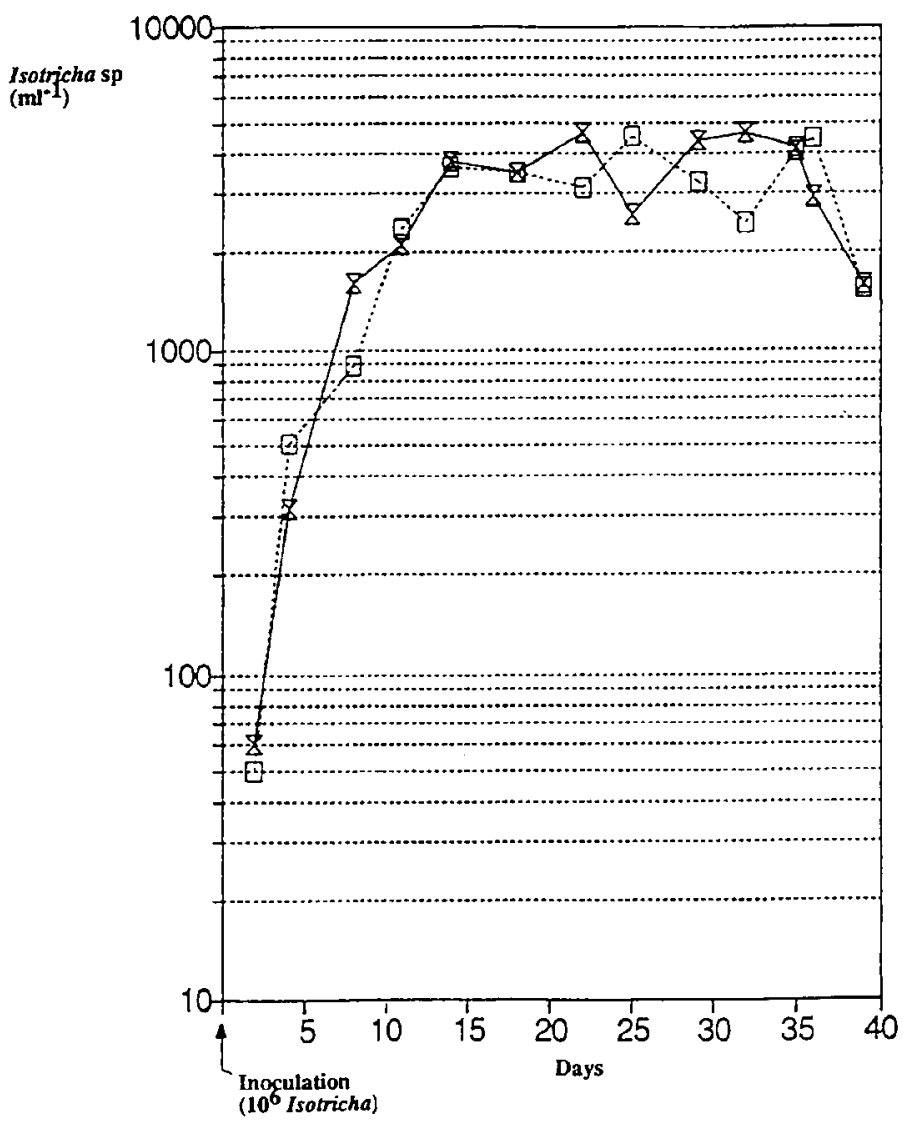

Fig 1. Establishment of Isotricha in a defaunated sheep rumen (sheep $A$ $\square$; sheep B \&). day 23 after inoculation at $2.0 \times 10^{4} / \mathrm{ml}$. In sheep A, Epidinium disappeared from days 6-13. From day 16, it had the same development as in sheep B. The population of Isotricha was unaffected by the introduction of the other 3 genera.

Once the protozoan population stabilized, it was composed of approximately $85 \%$ Entodinium, 10\% Epidinium, 3\% Eudiplodinium and $2 \%$ Isotricha. This is consistent with the bibliographic data (Jouany, 1989). The volume and biomass of ciliates (table I) were about 2.6 times greater in the rumen of mixed faunated sheep than in that of Isotricha monoinoculated animals.

\section{Evolution of protozoa population after feeding}

The number of Isotricha increased slightly in the rumen after feeding, in both the monoinoculated and mixed-faunated animals. Because of large variations in Isotricha concentrations from one day to another, the curve (fig $3 A$ ) gives the impression that the concentration of /sotricha varies little throughout the day. On the contrary, the number of entodiniomorphid ciliates decreased severely during the $3 \mathrm{~h}$ following the meal and increased $6 \mathrm{~h}$ after feeding (fig 3B). 


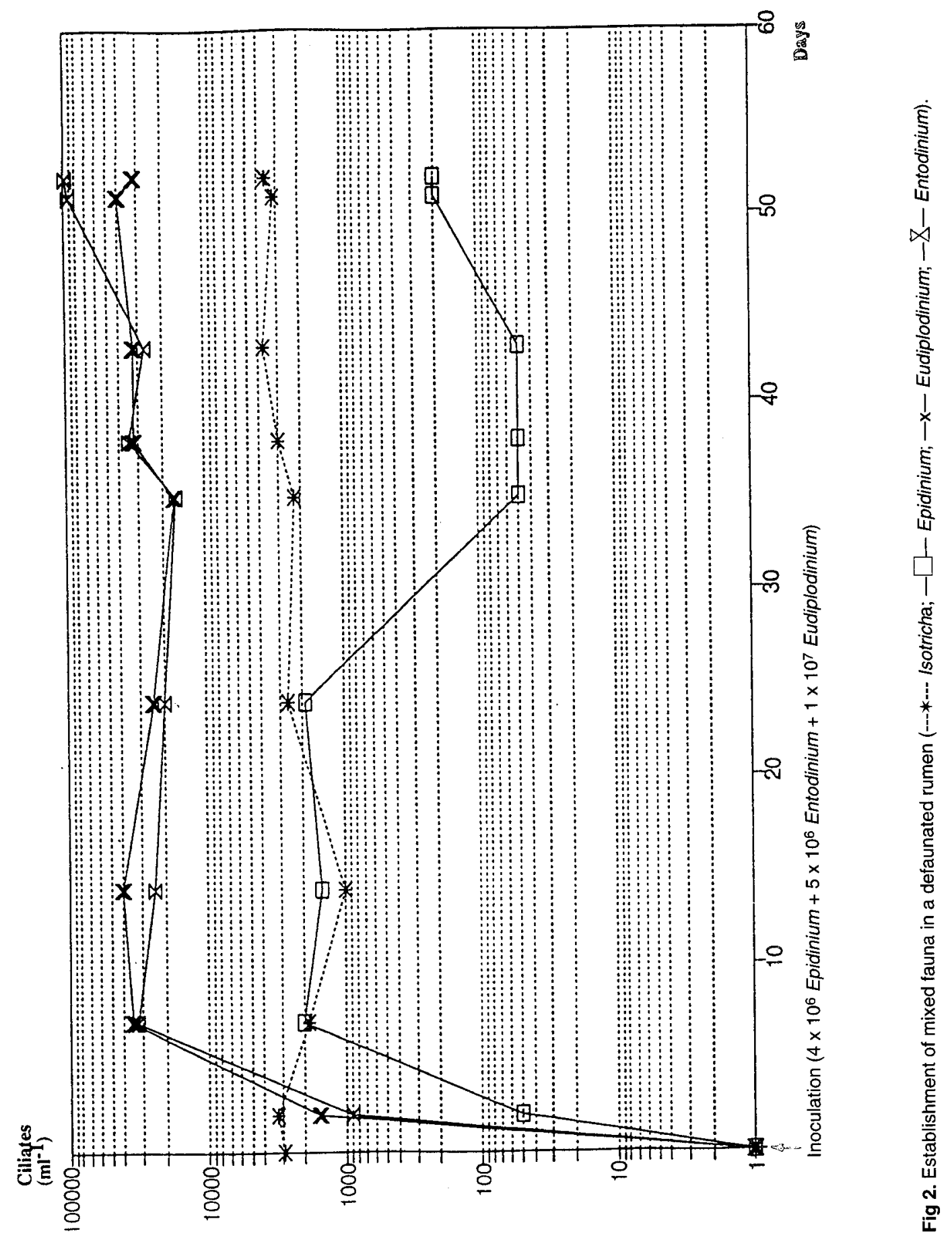


Table I. Concentration, volume and dry weight of protozoa in the rumen during the 3 periods.

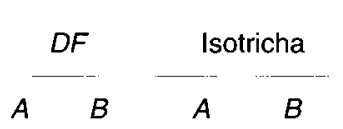

\begin{tabular}{|c|c|}
\hline$T F$ & Protozoa \\
\hline & \\
\hline
\end{tabular}

Protozoa concentration ( $\times 10^{-3} / \mathrm{ml}$ )

Isotricha sp

Entodinium sp

Eudiplodinium sp

Epidinium $\mathrm{sp}$

$\begin{array}{cccccccc}0 & 0 & 9.7 & 10.8 & 9.7 & 9.1 & \text { NS } & \text { NS } \\ 0 & 0 & 0 & 0 & 220 & 280 & - & - \\ 0 & 0 & 0 & 0 & 10.3 & 8.9 & - & - \\ 0 & 0 & 0 & 0 & 15.6 & 14.4 & - & -\end{array}$

Approximate volume of ciliate $(\mathrm{ml})$ in 1 I of digesta

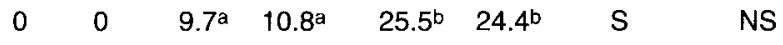

Approximate DM weight of ciliates $(\mathrm{g})$ in $1 \mathrm{I}$ of digesta

$\begin{array}{cccccccc}0 & 0 & 1.7^{\mathrm{a}} & 1.9^{\mathrm{a}} & 4.7^{\mathrm{b}} & 4.6^{\mathrm{b}} & \mathrm{S} & \mathrm{NS} \\ 4.72 & 4.87 & 4.30 & 4.87 & 3.30 & 4.12 & \text { NS } & \text { NS }\end{array}$

Bacteria counts $\left(10^{9} \mathrm{ml}^{-1}\right)$

$\begin{array}{ll}4.30 & 4.87\end{array}$

3.30

NS

Means with different superscripts on a line are significantly different $(P \leq 0.05)$; $D F=$ defaunated; $T F=$ total fauna; NS $=$ not significant; $S=$ significantly different $(P \leq 0.05)$.

\section{Bacteria counts}

Because of the large variations in bacteria counts between days for the same animal, and between animals for the same day, statistical analysis showed no effect $(p<0.05)$ of the addition of protozoa (/sotricha or mixed fauna) to defaunated rumens on bacteria concentrations (table I). Given that there were no significant differences between sheep $A$ and $B$ in protozoa and bacteria populations, the results obtained from the 2 animals have been pooled in the tables. However, they were separately

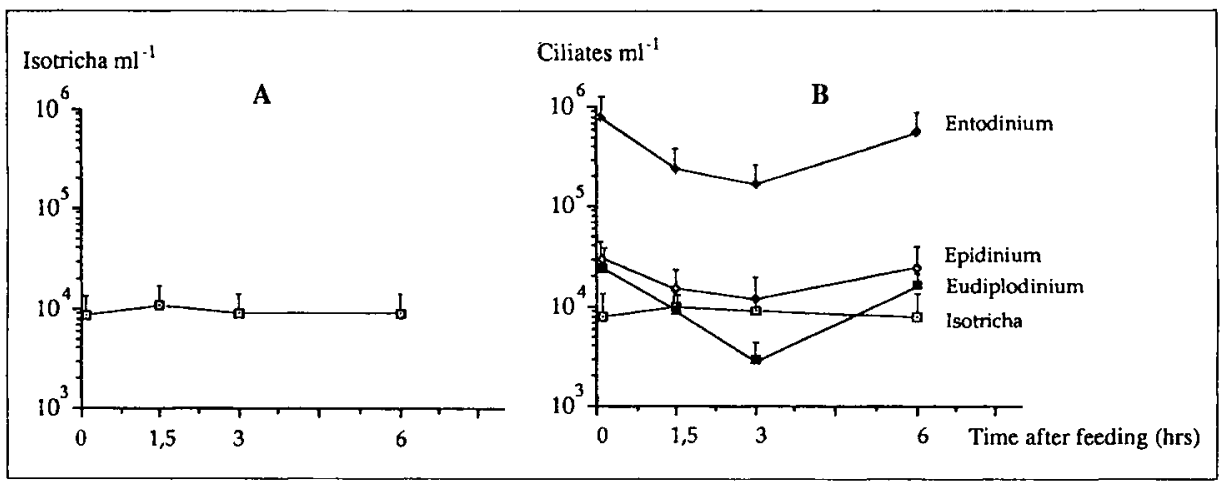

Fig 3. Evolution of protozoa concentrations in the rumen juice of monoinoculated animals (curve $A$ ) and mixed-faunated animals (curves B) after feed intake. 
analyzed by statistical analyses to study the animal effect.

\section{Adenylic nucleotides}

Before feeding, ATP and ADP concentrations in the filtered rumen content were higher $(p<0.05)$ in inoculated sheep than in defaunated ones, regardless of the nature of the fauna. With the exception of defaunated animals, they decreased after feeding, and ATP concentrations remained low for a longer time after feeding with the mixed fauna than with /sotricha alone (table II).

AMP concentrations were always lower in faunated rumens than in defaunated ones,

Table II. Influence of the rumen fauna on the adenylic nucleotide concentrations in the rumen contents.

\begin{tabular}{|c|c|c|c|c|c|c|c|}
\hline \multirow[t]{2}{*}{ Parameter } & \multirow{2}{*}{$\begin{array}{c}\text { Time afte } \\
\text { feeding } \\
\text { (h) }\end{array}$} & \multicolumn{4}{|c|}{ Animal } & \multirow[b]{2}{*}{$\begin{array}{c}\text { Protozoa } \\
\text { effect }\end{array}$} & \multirow[b]{2}{*}{$\begin{array}{l}\text { Anima } \\
\text { effect }\end{array}$} \\
\hline & & Protozoa-free & $\begin{array}{l}\text { Inoculated } \\
\text { with Isotricha }\end{array}$ & $\begin{array}{l}\text { Inoculated with } \\
\text { mixed fauna }\end{array}$ & $S D$ & & \\
\hline \multirow[t]{5}{*}{$\operatorname{ATP}\left(\times 10^{3} \mathrm{pmol} \mathrm{ml}^{-1}\right)$} & 0 & $3.5^{\mathrm{a}}$ & $18.0^{\mathrm{b}}$ & $22.0^{b}$ & 3.7 & $S$ & NS \\
\hline & 3 & $2.5^{\mathrm{a}}$ & $0.3^{b}$ & $0.3^{b}$ & 0.4 & S & NS \\
\hline & 6 & $6.5^{a}$ & $6.5^{\mathrm{a}}$ & $0.8^{b}$ & 2.9 & $S$ & NS \\
\hline & 12 & $6.5^{a}$ & $6.5^{\mathrm{a}}$ & $0.9^{b}$ & 2.7 & $\mathrm{~S}$ & NS \\
\hline & 18 & 9.5 & 15.0 & 17.5 & 6.5 & $S$ & NS \\
\hline \multirow[t]{5}{*}{$\mathrm{ADP}\left(\times 10^{3} \mathrm{pmol} \mathrm{ml-1}\right)$} & 0 & $3.5^{\mathrm{a}}$ & $17.0^{\mathrm{b}}$ & $15.5^{\mathrm{b}}$ & 3.5 & $S$ & NS \\
\hline & 3 & $6.5^{a}$ & $3.0^{b}$ & $1.3^{b}$ & 1.7 & $S$ & NS \\
\hline & 6 & $8.5^{\mathrm{a}}$ & $15.0^{\mathrm{b}}$ & $5.5^{\mathrm{a}}$ & 5.5 & $\mathrm{~S}$ & NS \\
\hline & 12 & $12.0^{\mathrm{ab}}$ & $19.0^{a}$ & $5.5^{b}$ & 7.5 & $S$ & $S$ \\
\hline & 18 & $5.5^{\mathrm{a}}$ & $17.0^{\mathrm{b}}$ & $12.0^{\mathrm{c}}$ & 2.5 & $\mathrm{~S}$ & NS \\
\hline \multirow[t]{5}{*}{ AMP $\left(\times 10^{3} \mathrm{pmol} \mathrm{ml}^{-1}\right)$} & 0 & 2.0 & 1.7 & 1.1 & 1.0 & NS & NS \\
\hline & 3 & $8.0^{a}$ & $0.8^{b}$ & $0.3^{b}$ & 3.0 & $S$ & NS \\
\hline & 6 & $7.5^{\mathrm{a}}$ & $1.4^{b}$ & $0.8^{b}$ & 0.8 & $S$ & NS \\
\hline & 12 & $11.5^{\mathrm{a}}$ & $0.9^{b}$ & $0.75^{b}$ & 2.1 & $\mathrm{~S}$ & NS \\
\hline & 18 & $4.0^{\mathrm{a}}$ & $0.2^{b}$ & $0.35^{\mathrm{b}}$ & 0.6 & $S$ & NS \\
\hline \multirow{5}{*}{$\begin{array}{l}\text { Total adenylic nucleotides } \\
\left(\times 10^{3} \mathrm{pmol} \mathrm{m}^{-1}\right)\end{array}$} & es 0 & $9.0^{a}$ & $36.7^{b}$ & $38.6^{\mathrm{b}}$ & 7.4 & $S$ & NS \\
\hline & 3 & $17.0^{a}$ & $4.1^{b}$ & $1.9^{b}$ & 7.3 & $\mathrm{~S}$ & NS \\
\hline & 6 & $22.5^{a}$ & $22.9^{a}$ & $7.1^{b}$ & 9.2 & $S$ & NS \\
\hline & 12 & $30.0^{\mathrm{a}}$ & $26.4^{a}$ & $7.1^{b}$ & 12.5 & $S$ & NS \\
\hline & 18 & 19.0 & 32.2 & 29.8 & 13.7 & NS & NS \\
\hline \multirow[t]{5}{*}{ Energy charge } & 0 & $0.60^{a}$ & $0.71^{\mathrm{b}}$ & $0.70^{b}$ & 0.01 & $\mathrm{~S}$ & NS \\
\hline & 3 & $0.45^{a}$ & $0.47^{a}$ & $0.65^{b}$ & 3.1 & $S$ & NS \\
\hline & 6 & 0.48 & 0.55 & 0.52 & 5.8 & NS & NS \\
\hline & 12 & $0.45^{\mathrm{a}}$ & $0.55^{\mathrm{b}}$ & $0.54^{b}$ & 5.5 & $S$ & NS \\
\hline & 18 & 0.70 & 0.73 & 0.80 & 8.2 & NS & $\mathrm{S}$ \\
\hline
\end{tabular}

NS: not significant; S: significantly different $(P \leq 0.05)$; means with different superscripts were significantly different $(P \leq 0.05)$. 
but there were no significant differences $(p>$ 0.05 ) between treatments before feeding.

The total adenylic nucleotides (ATP + ADP + AMP) were significantly influenced by the inoculation of protozoa. They were highest in all faunated animals at times distant from the meal $\left(T_{18}\right.$ and $\left.T_{0}\right)$ and in defaunated animals and Isotricha-inoculated animals during the $12 \mathrm{~h}$ following the meal.

The energy charge (EC) was systematically greater in the faunated sheep, regardless of the nature of the fauna, but there was no significant difference $(p>0.05)$ between treatments 6 and $18 \mathrm{~h}$ after feeding.

\section{In vivo digestibility of the diet}

No significant difference was observed in diet digestibility after inoculation of either Isotricha alone or mixed fauna in the defaunated sheep rumen (table III).

\section{In situ degradation of NDF from 2 cellulosic substrates, wheat straw and lucerne stems}

The rate and level of wheat straw breakdown were lower in the complex mixed- fauna sheep than in the defaunated sheep for almost all sampling times (table IV). In contrast, the degradation rate of lucerne stems during the first $12 \mathrm{~h}$ was higher in the mixed fauna sheep while the plateau level obtained at $48 \mathrm{~h}$ was not influenced by the presence of any type of the tested protozoa. The addition of Isotricha alone into the defaunated rumens had little effect on the breakdown of either of the 2 substrates although a significant increase $(p=0.01)$ was observed in the Isotricha-inoculated rumens for lucerne at the sampling time of $6 \mathrm{~h}$, and for wheat straw at the sampling time of $24 \mathrm{~h}$.

\section{End products of microbial fermentation in the rumen}

The introduction of either fauna into a defaunated rumen had no significant effect on the $\mathrm{pH}$ value of rumen contents over the day (table V). In all cases $\mathrm{pH}$ fell to about 5.6 after feeding and remained at this level for at least $6 \mathrm{~h}$. The redox potential of the rumen juice was not measured in defaunated animals. It was not significantly different $(p>$ 0.05 ) in the Isotricha and mixed-fauna-inoculated animals.

The VFA concentration, which was low in sheep before feeding in all periods (from 50

Table III. Digestibility of the diet in the entire digestive tract.

\begin{tabular}{lccccc}
\hline $\begin{array}{l}\text { Digestible } \\
\text { fraction }\end{array}$ & Protozoa-free & $\begin{array}{c}\text { Digestibility in animals (\%) } \\
\text { Inoculated } \\
\text { with Isotricha }\end{array}$ & $\begin{array}{c}\text { Inoculated with } \\
\text { mixed fauna }\end{array}$ & Protozoa effect & Animal effect \\
& & & & & \\
DM & 70.3 & 69.8 & 71.7 & NS & NS \\
OM & 71.7 & 71.1 & 72.9 & NS & NS \\
N & 66.5 & 65.8 & 66.7 & NS & NS \\
NDF & 65.3 & 64.7 & 65.0 & NS & NS
\end{tabular}


Table IV. In sacco degradation of NDF fraction of wheat straw and lucerne stems.

\begin{tabular}{|c|c|c|c|c|c|c|}
\hline \multirow[t]{2}{*}{ Animal } & \multicolumn{6}{|c|}{ Time in rumen (h) } \\
\hline & 3 & 6 & 12 & 18 & 24 & 48 \\
\hline \multicolumn{7}{|c|}{ Wheat straw degradation (\%) } \\
\hline PF & - & $4.5^{\mathrm{a}}$ & 6.8 & 9.7 & $14.5^{\mathrm{a}}$ & $22.2^{\mathrm{a}}$ \\
\hline Iso & - & $4.5^{\mathrm{a}}$ & 7.3 & 12.0 & $18.4^{b}$ & $22.3^{a}$ \\
\hline $\mathrm{TF}$ & - & $2.7^{b}$ & 4.7 & 8.2 & $11.6^{c}$ & $17.9^{\mathrm{b}}$ \\
\hline SDM & - & 1.1 & 1.7 & 1.7 & 1.7 & 1.0 \\
\hline Protozoal effect & - & $\mathrm{S}$ & NS & NS & $\mathrm{s}$ & $S$ \\
\hline \multicolumn{7}{|c|}{ Lucerne degradation (\%) } \\
\hline PF & $16.2^{\mathrm{a}}$ & $17.6^{\mathrm{a}}$ & $23.0^{\mathrm{a}}$ & $31.9^{\mathrm{a}}$ & $38.5^{\mathrm{a}}$ & - \\
\hline Iso & $17.1^{\mathrm{a}}$ & $20.2^{b}$ & $26.2^{\mathrm{a}}$ & $32.9^{a}$ & $41.0^{\mathrm{a}}$ & _- \\
\hline TF & $20.0^{b}$ & $26.8^{c}$ & $31.6^{\mathrm{b}}$ & $34.9^{a}$ & $38.2^{\mathrm{a}}$ & - \\
\hline SDM & 1.5 & 1.0 & 1.9 & 1.6 & 1.8 & - \\
\hline Protozoal effect & $S$ & $\mathrm{~S}$ & $S$ & NS & $\mathrm{S}$ & - \\
\hline
\end{tabular}

Eight determinations were made. Means with different superscripts for the same substrate on a column, are significantly different $(P \leq 0.05)$; S: significant; NS: not significant; PF: protozoa-free; Iso: inoculated with Isotricha only; TF: faunated with a mixed fauna.

to $62 \mathrm{mM}$ ), rose markedly after feeding but remained at standard values. Lower values were observed in animals inoculated with a mixed fauna soon after the meal $(6 h)$ and later (18 h) in Isotricha-inoculated sheep.

The molar proportion of acetate in the VFA mixture was not significantly modified $(p>0.05)$ by the presence of any genus of protozoa in the rumen at any time after feeding. The addition of Isotricha to defaunated rumens induced a higher molar proportion of propionate $18 \mathrm{~h}$ after feeding; this increase persisted for the $6 \mathrm{~h}$ until the following meal. The addition of mixed fauna had the opposite effect. The molar proportion of propionate decreased from 18 to $24 \mathrm{~h}$ after feeding. The proportion of butyrate systematically increased $(p<0.001)$ at the expense of valerate in the presence of the mixed fauna throughout the $24 \mathrm{~h}$ cycle, as did the presence of Isotricha before feeding. However, during the $18 \mathrm{~h}$-period after feeding, the addition of Isotricha in defaunated rumens had no effect on butyrate proportion.

$\mathrm{NH}_{3}-\mathrm{N}$ concentration increased markedly in the presence of the mixed fauna and the significant threshold was only reached in samples taken $6 \mathrm{~h}$ after feeding. It was not affected by the inoculation of /sotricha alone into the defaunated rumen.

\section{DISCUSSION}

The pattern of protozoal development during the growth phases was consistent with that described by Sénaud et al (1980) and Grolière et al (1980). It is noteworthy that the numbers reached at the end of the growth period always exceeded the subsequent plateau value. This shows that the equilibrium of the microbial ecosystem is governed by interactions between microorganisms (/sotricha, bacteria or fungi in 
Table V. Influence of protozoa on the end products of rumen fermentations.

\begin{tabular}{|c|c|c|c|c|c|c|}
\hline \multirow[t]{2}{*}{ Parameter } & \multirow{2}{*}{$\begin{array}{l}\text { Time after } \\
\text { feeding }(h)\end{array}$} & \multicolumn{5}{|c|}{ Animal } \\
\hline & & Protozoa-free & $\begin{array}{c}\text { Inoculated } \\
\text { with Isotricha }\end{array}$ & $\begin{array}{l}\text { Inoculated with } \\
\text { mixed fauna }\end{array}$ & $S D M$ & $\begin{array}{l}\text { Protozoal } \\
\text { effect }\end{array}$ \\
\hline \multirow[t]{4}{*}{$\mathrm{pH}$} & 0 & 7.03 & 7.01 & 7.00 & 0.15 & NS \\
\hline & 3 & 5.58 & 5.64 & 5.65 & 0.14 & NS \\
\hline & 6 & 5.63 & 5.65 & 5.68 & 0.12 & NS \\
\hline & 18 & 6.47 & 6.47 & 6.42 & 0.13 & NS \\
\hline \multirow[t]{4}{*}{ Eh (mV) } & 0 & ND & -256 & -304 & 51 & NS \\
\hline & 3 & ND & -224 & -193 & 49 & NS \\
\hline & 6 & ND & -205 & -209 & 15 & NS \\
\hline & 18 & ND & -272 & -272 & 26 & NS \\
\hline \multirow[t]{4}{*}{ VFA (mM) } & 0 & 62 & 50 & 50 & 11 & NS \\
\hline & 3 & 137 & 125 & 102 & 39 & NS \\
\hline & 6 & $112^{a}$ & $111^{a}$ & $81^{b}$ & 18 & $\mathrm{~S}$ \\
\hline & 18 & $80^{a}$ & $52^{b}$ & $63^{a b}$ & 11 & $S$ \\
\hline \multirow[t]{4}{*}{ Acetate (molar\%) } & 0 & 68.9 & 67.1 & 67.6 & 2.0 & NS \\
\hline & 3 & 68.6 & 67.4 & 66.3 & 1.9 & NS \\
\hline & 6 & 67.8 & 67.0 & 65.8 & 1.5 & NS \\
\hline & 18 & 70.0 & 68.9 & 68.2 & 2.0 & NS \\
\hline \multirow[t]{4}{*}{ Propionate (molar \%) } & 0 & $18.8^{\mathrm{a}}$ & $20.4^{b}$ & $15.7^{c}$ & 1.0 & $S$ \\
\hline & 3 & 20.1 & 21.2 & 19.3 & 1.8 & NS \\
\hline & 6 & 18.6 & 20.6 & 19.3 & 1.5 & NS \\
\hline & 18 & $17.4^{\mathrm{a}}$ & $19.2^{b}$ & $15.9^{\mathrm{c}}$ & 1.0 & $S$ \\
\hline \multirow[t]{4}{*}{ Butyrate (molar \%) } & 0 & $5.9^{\mathrm{a}}$ & $8.5^{\mathrm{b}}$ & $10.6^{c}$ & 1.0 & S \\
\hline & 3 & $8.6^{\mathrm{a}}$ & $9.2^{\mathrm{a}}$ & $12.4^{\mathrm{b}}$ & 1.0 & 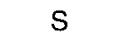 \\
\hline & 6 & $10.3^{a}$ & $10.1^{a}$ & $12.7^{b}$ & 0.8 & $S$ \\
\hline & 18 & $8.2^{\mathrm{a}}$ & $8.5^{\mathrm{a}}$ & $12.6^{b}$ & 1.1 & $S$ \\
\hline \multirow[t]{4}{*}{ Valerate (molar \%) } & 0 & $1.0^{\mathrm{a}}$ & $0.75^{b}$ & $0.97^{a}$ & 0.14 & $S$ \\
\hline & 3 & $1.2^{\mathrm{a}}$ & $0.80^{\mathrm{b}}$ & $0.77^{b}$ & 0.15 & $S$ \\
\hline & 6 & $1.7^{\mathrm{a}}$ & $0.95^{b}$ & $1.05^{b}$ & 0.15 & $S$ \\
\hline & 18 & $1.2^{\mathrm{a}}$ & $0.85^{b}$ & $0.93^{b}$ & 0.11 & $S$ \\
\hline \multirow[t]{4}{*}{ Caproate (molar \%) } & 0 & 0.13 & 0.37 & 0.29 & 0.15 & NS \\
\hline & 3 & 0.31 & 0.24 & 0.30 & 0.05 & NS \\
\hline & 6 & $0.54^{a}$ & $0.35^{\mathrm{b}}$ & $0.43^{\mathrm{ab}}$ & 0.10 & $S$ \\
\hline & 18 & $0.30^{\mathrm{a}}$ & $0.22^{\mathrm{b}}$ & $0.38^{c}$ & 0.04 & $\mathrm{~S}$ \\
\hline \multirow[t]{4}{*}{$\mathrm{NH}_{3}-\mathrm{N}(\mathrm{mg} / \mathrm{l})$} & 0 & $110^{a}$ & $140^{a}$ & $299^{b}$ & 34 & $S$ \\
\hline & 3 & $144^{a}$ & $170^{a b}$ & $202^{b}$ & 30 & $S$ \\
\hline & 6 & $70^{\mathrm{a}}$ & $115^{a b}$ & $135^{b}$ & 37 & $S$ \\
\hline & 18 & $83^{a b}$ & $53^{a}$ & $117^{\mathrm{b}}$ & 35 & $S$ \\
\hline
\end{tabular}

Number of determinations $=8$; ND: not determined; NS: not significant; S: significantly different $(P \leq 0.05)$; means with different superscripts on the same line are significantly different $(P \leq 0.05)$. 
monoinoculated sheep, and additional interactions between protozoa in mixed-fauna animals), and requires some $10 \mathrm{~d}$ to stabilize.

It is generally accepted that highly acidic $\mathrm{pH}$ values in the rumen can inhibit the growth of ciliates (Purser and Moir, 1959) and may even cause their complete elimination (Eadie et al, 1970; Whitelaw et al, 1972; Rung et al, 1986). The decline in the number of entodiniomorphid ciliates noted here during the $3 \mathrm{~h}$ following the meal in the rumen juice was always observed in the numerous experiments we carried out. We consider that it is more due to the migration of protozoa towards the matrix of solid particles and to dilution effect than a direct effect of $\mathrm{pH}$ because it also appears when animals are fed with hay and straw diets (see Jouany et al, 1973; Jouany 1978). Furthermore, the present results show that with a $\mathrm{pH}$ of about 5.6 that persists for about $6 \mathrm{~h}$ after feeding and with a normal molar proportion of propionate in the VFA mixture ( $\mathrm{ca}$ $20 \%$ ), the ciliate population in the rumen can be large. It is possible that the propionate concentration is the main factor in the elimination of ciliates sometimes observed with starch-rich diets as reported by Kobayashi and Itabashi (1986).

Contrary to most studies showing that defaunation decreases bacterial population (see Williams and Coleman, 1992), the absence of any effect observed here could be due to the fact that determinations were made on total counts instead of viable counts.

The very low values of adenylic nucleotides we observed, compared to those of Wallace and West (1982) and Erfle et al (1986), could have been due to losses during sampling, although extractions were done no more than $8 \mathrm{~min}$ after rumen contents were removed from the rumen, or to the disturbance of rumen microbes related to large amounts of highly fermentable starch. A more plausible reason is that a large majority of microbes were eliminated from our liquid samples during the filtration of solid particles. We can therefore consider that these results concern only the liquidassociated bacteria and protozoa.

As indicated previously by many authors, the meaning of adenylic nucleotides in the rumen is difficult to assess. Although they have been used in various ecological systems (Karl, 1980) as biomass indicators, they have been estimated as poor evaluators for rumen microbes.

ATP has been proposed as an indicator of microbial metabolic activity (Wolstrup and Jensen, 1978). According to Erfle et al (1986), it is not a reliable marker for this microbial characteristic. Like Swedes et al (1975), Erfle et al (1986) suggest using the adenylate energy charge (EC) to estimate protein synthesis (growth and enzyme production) and metabolic activity in microbial cells. However, at the present, no reliable relationship between metabolic activity of microbes and adenylic nucleotide content has been established (Erfle et al, 1986).

The decrease in concentration of ATP, ADP and total adenylic nucleotides in the rumen juice of faunated animals after feeding is mainly explained by the migration of most microbes towards the solid phase and also by a decline in ciliate numbers in the mixed faunated rumens, protozoa being richer than bacteria in ATP and ADP (Fosberg and Lam, 1977). The same relationship between adenylic nucleotide concentration and protozoal biomass has been observed using Rusitec (Bohatier et al, 1992). However, it is difficult to explain the decrease in adenylic nucleotides after feeding the monoinoculated sheep since the number of Isotricha increased slightly during that time. Differences in adenylic nucleotides between the 2 types of faunated sheep were negligible or in favour of monoinoculated sheep although the population of protozoa was higher in the former. The increase in adenylic nucleotides that is noted after the 
feeding of the defaunated sheep could indicate that more energy was available to the bacteria in these animals. Furthermore, the large ingestion of starch granules by protozoa left less energy available for the bacteria in faunated animals. We also noted that the level of adenylic nucleotides was very low in starved defaunated sheep while the slow digestive process of starch by protozoa and their sequestration within the rumen of faunated animals maintained a high energy content in microbes $24 \mathrm{~h}$ after feed intake in these animals.

Our results indicate that EC increased after the addition of protozoa to defaunated rumens. Unlike Erfle et al (1979) who reported a slight increase in EC after feeding, or Wallace and West (1982) who noted no EC variation during the day, we observed an EC decrease in the rumen of all animals after feeding whatever the fauna. The EC values, like ATP values, were low, especially in the defaunated animals and after feeding in all periods, which could suggest that rumen microbial dysfunctions occurred under our feeding conditions although no lactate was detected in the rumen. This may have been due to unstable microbial metabolic activity which occurs when large amounts of starch are fermented in the rumen (Martin and Michalet-Doreau, 1995). This effect is amplified when protozoa are absent. The variations in EC between animals or between days, estimated by standard deviation values (table I), were low before feeding, but increased a great deal after a feeding.

The intake of large amounts of barley in 1 daily ration had a negative effect on the cell-wall carbohydrate digestibility of the diet. This result was confirmed by the low in situ degradation of lucerne stems and wheat straw. Martin (1994) observed from a large analysis of bibliographic data that both the rate and level of degradation are affected by an increased starch percentage in the diet; the effect is magnified when high fer- mentable starch like barley is used in the feed.

The conflicting effects of protozoa on the in situ degradation of the 2 cellulosic substrates studied (wheat straw and lucerne stems) are difficult to account for. They are probably due to the differences in anatomical structure and chemical organization of cell-wall components between a grass (monocotyledon) and a legume (dicotyledon). A cross-section of straw reveals a cutinized epidermis, a cortical parenchyma, a sclerenchyma annulus and vascular bundles (phloem + xylem) arranged in circles in the medullar parenchyma. Straw cells are almost exclusively made up of walls as they no longer contain cytoplasm. The epidermal cuticle of the lucerne stem is thinner. Patches of phloem surrounded by collenchyma and cambium are associated with the xylem, giving the whole a collar shape within the parenchyma. After about $10 \mathrm{~h}$ all that remains of the lucerne stems is the lignified crown of xylem. Over the same period, only the mesophyll cells of straw are degraded (Grenet and Demarquilly, 1987). Bauchop and Clarke (1976) and Sénaud et al (1986) showed that the ciliate protozoa (mainly Epidinium sp) rapidly colonize the lucerne stems (in less than $15 \mathrm{~min}$ ) and break down the tissues situated between the epidermis and the vascular cylinder. In contrast, the ciliates do not fix on wheat straw to any extent. Because they must ingest small particles and soluble substrates to digest them, the action of extracellular enzymes is not efficient in protozoa (Akin and Amos, 1979). This selective behaviour towards the 2 substrates tested may explain the positive action of ciliates on the breakdown of lucerne and the negative effect on straw. In addition, the chemical composition of the walls of the 2 tested substrates is different. According to Jarrige (1981), the levels of xylans, glucans and lignin are higher in straw than in lucerne. Legume walls also contain no phenolic acids. 
VFA concentration remained normal after feeding even though the sheep ingested large amounts of starch in a short time since all the diet was consumed in $20 \mathrm{~min}$. The concentration was low in samples taken $18 \mathrm{~h}$ later. Due to low $\mathrm{pH}$, VFA absorption was probably intense during the few hours following feed intake. The drop in VFA concentration observed after inoculation of ciliates, at variance with the findings of most other studies (cf Jouany, 1991), may have been due to the ingestion and storage of large amounts of starch granules by protozoa. The starch is then digested slowly throughout the day or even flows out to the small intestine with the ciliates (Mendoza et al, 1993). The increased butyrate proportion of the VFA mixture in the faunated sheep, at the expense of propionate and valerate, is consistent with previously published results (Jouany et al, 1988). This trend was less marked in Isotricha-monoinoculated sheep than in mixed-faunated sheep, and is probably the direct consequence of butyrate production by the entodiniomorphid ciliates (Eadie et al, 1970). On the other hand, the lactate that could be produced with such diets was never detected in the sheep rumen juice throughout the experiment. It was probably metabolized by ciliates into propionate in the faunated animals (Chamberlain et al, 1983; Newbold et al, 1985), and could explain why there was not the expected decrease in propionate (Jouany, 1991). In defaunated animals, lactate can be transformed into butyrate by bacteria (Jouany, 1991) which explains why the level of this VFA was maintained when protozoa were absent.

The higher concentration of $\mathrm{NH}_{3}-\mathrm{N}$ in the rumen content of the complex mixed-fauna animals compared with defaunated or Isotricha-monoinoculated animals is mainly due to the hydrolytic and fermenting action of the entodiniomorphid ciliates on the dietary and microbial proteins in the rumen (Ushida et al, 1991) assuming, as reported by Itabashi and Kandatsu (1975), that the $\mathrm{NH}_{3}-\mathrm{N}$ uptake by the bacteria is not modified by the addition of protozoa to a defaunated rumen. The absence of any response to monoinoculation of Isotricha in a defaunated rumen on $\mathrm{NH}_{3}-\mathrm{N}$ concentration is explained by the low deaminating activity of rumen microbes in the presence of Isotricha, as shown in vitro by Jouany et al (1992). This means that the presence of /sotricha as the sole protozoa improves cellulolysis as compared to defaunated animals and decreases deamination in the rumen as compared to mixed-faunated animals. This result is of importance for the nutrition of ruminants.

\section{CONCLUSION}

The physiological state of liquid-associated rumen microbes estimated by their adenylic nucleotide concentration was largely influenced by the presence of protozoa. Some instability in the growth and enzyme production of rumen microbes could be revealed by the high variations in the ruminal total amount of adenylic nucleotides and the energy charge throughout the day in sheep fed a starch-rich diet in 1 daily ration.

The mixed fauna limited the negative effect of starch on the digestion of lucerne to a larger extent than Isotricha. This could be due to the withdrawal of starch from the rumen content by ciliates. Such a result is in good agreement with the proposal made by Ushida et al (1991) concerning the effect of protozoa on cell-wall carbohydrate digestion in the rumen.

Finally, it was confirmed that a mixed population of protozoa has a detrimental effect on protein utilization in ruminants, while the deaminating activity of rumen microbes was significantly decreased when Isotricha was alone as previously shown in vitro (Jouany et al, 1992) and in vivo (Jouany et al, 1995). This could mean that the amino 
acid supply to ruminants is higher in Isotricha-monoinoculated animals. Such a hypothesis must be confirmed by in vivo digestion trials using sheep fitted with duodenal fistula. The decrease in $\mathrm{NH}_{3}-\mathrm{N}$ concentration in these animals could limit nitrogen excretion in urine and be of interest in the consideration of nitrogen pollution in relation to husbandry.

\section{ACKNOWLEDGMENTS}

The authors are grateful to M De Courtenay for his contribution to this experiment. They wish to thank $\mathrm{J}$ Lefaivre, M Fabre, $\mathrm{P}$ Journaix and $\mathrm{S}$ Toillon for their skilled technical assistance.

\section{REFERENCES}

Akin DE, Amos HE (1979) Mode of attack on Orchardgrass leaf blades by rumen protozoa. Appl Environ Microb 37, 332-338

Atkinson DE, Walton GM (1967) Adenosine triphosphate conservation in metabolic regulation. $J$ Biol Chem 242, 3239-3241

Bauchop T, Clarke RTJ (1976) Attachment of the ciliate Epidinium crawley to plant fragments in the sheep rumen. Appl Environ Microb 32, 417-422

Bergström I, Heinänen A, Salonen K (1986) Comparison of acridine orange, acriflavine and bisbenzimide stains for enumeration of bacteria in clear and humic water. App/ Environ Microb 51, 664-667

Bird SH, Leng RA (1978) The effects of defaunation of the rumen on the growth of lambs on low-protein high-energy diets. Br J Nutr 42, 81-87

Bird SH, Leng RA (1984) Further studies on the effects of the presence or absence of protozoa in the rumen on live-weight gain and wool growth of sheep. $\mathrm{Br} J$ Nutr 52, 607-611

Bird SH, Hill MK, Leng RA (1979) The effects of defaunation of the rumen on the growth of lambs on lowprotein high-energy diets. Br J Nutr 42, 81-87

Bohatier J, Senaud J, Senhaji M (1992) Use of adenosine $5^{\prime}$-triphosphate nucleotide pool as an indicator of biomass and physiological activity of ruminal microbial population in sheep and in artificial fermentor (Rusitec). Arch Protistenkd 142, 59-75

Broad TE, Dawson RMC (1975) Phospholipid biosynthesis in the anaerobic protozoa Entodinium caudatum. Biochem J 146, 317-328
Chamberlain DG, Thomas PC, Henderson FG (1983) Volatile fatty acid proportions and lactic acid metabolism in the rumen of sheep and cattle receiving silage diets. J Agric Sci Camb 101, 47-58

Eadie JM, Hyldgaard-Jensen J, Mann SO, Reid RS, Whitelaw FG (1970) Observations on the microbiology and biochemistry of the rumen cattle given different quantities of a pelleted barley ration. $\mathrm{Br} J$ Nutr 24, 157-177

Erfle JD, Mahadevan S, Sauer FD (1979) Relationship between adenylate energy charge, rumen volatile fatty acid concentrations, and rates of production and dry matter digestibility in the cow. J Dairy Sci 64, 634-642

Erfle JD, Sauer FD, Mahadevan S (1986) Energy metabolism in rumen microbes. In: Control of Digestion and Metabolism in Ruminants (LP Milligan, WL Grovum, A Dobson, eds), Prentice-Hall, Englewoods Cliffs, New Jersey, USA, 81-99

Forsberg CW, Lam K (1977) Use of adenosine 5'-triphosphate as an indicator of the microbiota biomass in rumen contents. Environ Microb 33, 528-537

Grenet E, Demarquilly C (1987) Rappels sur la digestion des fourrages dans le rumen (parois) et ses conséquences. In: Les fourrages secs : récolte, traitement, utilisation (C Demarquilly, ed), INRA, Paris, France, 141-162

Grolière CA, Senaud J, Jouany JP, Grain J, de Puytorac $P$ (1980) Implantation et développement des populations de protozoaires ciliés (Polyplastron multivesiculatum, Entodinium $\mathrm{sp}$, Isotricha prostoma) dans le rumen de moutons recevant différents régimes alimentaires. II. Régimes à base de foin, enrichis en céréales. Protistologica 16, 385-394

Itabashi H, Kandatsu M (1975) Influence of rumen ciliate protozoa on the concentration of ammonia and volatile fatty acid in connection with the utilization of ammonia in the rumen. Jpn J Zootech Sci 46, 409416

Itabashi $\mathrm{H}$, Kobayashi T, Matsumato $\mathrm{M}$, Takenaka $\mathrm{A}$ (1989) Effect on unfaunation on plasma-free aminoacids, gastrin and insulin, and duodenal nitrogen flow in ruminants. Asian-Australas Sci 2, 489-490

Jackubczak E, Leclerc H (1981) Mesure de I'ATP bactérien par bioluminescence. Étude cinétique des méthodes d'extraction. Ann Biol Clin 38, 287-304

Jarrige $R$ (1981) Les constituants glucidiques des fourrages : variation, digestibilité et dosage. In: Prévision de la valeur nutritive des aliments des ruminants. INRA Publications, Versailles, France, 13-40

Jouany JP (1978) Contribution à l'étude des protozoaires ciliés du rumen, leur dynamique, leur rôle dans la digestion et leur intérêt pour le ruminant. Thèse Doctorat, Université Clermont II, France

Jouany JP (1982) Volatile fatty acid and alcohol determination in digestive contents, silage juices, bacterial cultures and anaerobic fermentor contents. Sci Alim 2, 131-144 
Jouany JP (1989) Effect of diet on populations of rumen protozoa in relation to fibre digestion. In: The Roles of Protozoa and Fungi in Ruminant Digestion (JV Nolan, RA Leng, DI Demeyer, eds) Penambul Books, Armidale, NSW, Australia, 59-74

Jouany JP (1991) Rumen Microbial Metabolism and Ruminant Digestion (JP Jouany, ed) INRA Éditions, Science Update, Versailles, France, $374 p$

Jouany JP, Sénaud J (1979) Défaunation du rumen de mouton. Ann Biol Anim Bioch Bioph 19, 619-624

Jouany JP, Sénaud J, Grain J, de Puytorac P (1973) Observations sur la dynamique des populations de Polyplastron multivesiculatum et d'Entodinium $\mathrm{sp}$ (ciliés oligotriches) dans le rumen du mouton. Ann Biol Anim Bioch Biophys 13, 741-745

Jouany JP, Demeyer DI, Grain J (1988) Effect of defaunating the rumen. Anim Feed Sci Techn 21, 229-265

Jouany JP, Ivan M, Papon Y, Lassalas B (1992) Effects of Isotricha, Eudiplodinium, Epidinium + Entodinium and a mixed population of rumen protozoa on the in vitro degradation of fishmeal, soybean meal and casein. Can J Anim Sci 72, 871-880

Jouany JP, Sénaud J, Toillon S, Bohatier J, Ben Salah M, Prensier G (1995) Effect of inoculation of /sotricha alone, or a mixed-type B fauna in a defaunated rumen on the digestion of a lucerne-maize diet (70:30) in sheep. Reprod Nutr Develop 35, 11-25

Karl DM (1980) Cellular nucleotide measurements and applications in microbial ecology. Microbiol Rev 414, 739-796

Kobayashi T, Itabashi H (1986) Effect of intra-ruminal VFA infusion on the protozoal populations of the rumen. Bull Nat/ Inst Anim Ind 44, 47-54

Leng RA, Gill M, Kempton TJ et al (1981) Kinetics of large ciliate protozoa in the rumen of cattle given sugar cane diets. Br J Nutr 46, 371-384

Martin C (1994) Lois de réponse de la dégradation des constituants pariétaux aux variations du $\mathrm{pH}$ ruminal. Thèse d'Université Blaise-Pascal, Clermont II, France

Martin C, Michalet-Doreau B (1995) Variations in mass and enzyme activity of rumen microorganisms: effect of barley and buffer supplements. I Sci Food Agric $67,407-413$

Mendoza GD, Britton RA, Stock RA (1993) Influence of rumen protozoa on site and extent of starch digestion and ruminal fermentation. $J$ Anim Sci 71, 1572-1578

Newbold CJ, Chamberlain DG, Williams AG (1985) Ruminal metabolism of lactic acid in sheep receiving a diet of sugar beet pulp and hay. Proc Nutr Soc 44, 85A

Pradet A (1967) Étude des adénosines 5'-mono, di et triphosphates dans les tissus végétaux. 1. Dosages enzymatiques. Physiol Veget 5, 209-221

Prévot S (1990) Étude du comportement des populations de ciliés et de bactéries dans un fermenteur semi-continu (Rusitec) en phase d'adaptation ; suivi de certaines espèces bactériennes par immuno- fluorescence. Essai de maintien de microorganismes dans le fermenteur par variation de paramètres physiques, chimiques et biotiques. Thèse, université Blaise-Pascal. Clermont-Ferrand, France

Prévot S, Senhaji M, Bohatier J, Sénaud J (1988) Comptage par épifluorescence des bactéries du rumen cultivées in vitro. Estimation de leur état physiologique. Reprod Nutr Dévelop 28, 137-138

Punia BS, Leibholz J, Faichney GJ (1987) The role of rumen protozoa in the utilization of paspalum (Paspalum dilatum) hay by cattle. Br J Nutr $57,395-406$

Purser DB, Moir RJ (1959) Ruminal flora studies in the sheep. IX. The effect of $\mathrm{pH}$ on the ciliate population of the rumen in vivo. Austr J Agric Res 10, 555-564

Rung G, Sekiguchi M, Imai S (1986) Changes in rumen ciliates and in rumen fluid caused by excessive brewer's grain feeding and restauration of them. Jpn J Zootech Sci 57, 887-894

SAS (1985) SAS User's Guide: Statistics. SAS Institute Inc, Cary, NC, USA

Sénaud J, Grolière CA, Zainab B, Grain J, Jouany JP (1980) Implantation et développement des populations de protozoaires ciliés (Polyplastron multivesiculatum, Entodinium sp, Isotricha prostoma) dans le rumen de moutons recevant différents régimes alimentaires. I. Régime luzerne-orge (40/50). Protistologica 16, 329-337

Sénaud J, Bohatier J, Grain J (1986) Comportement du cilié du rumen Epidinium caudatum en présence de fragments de luzerne : étude en microscopie électronique à balayage. Protistologica 22, 111-116

Strehler BL, Tötter JR (1954) Determination of ATP and related compounds. In: Methods of Biochemical Analysis (D Glick, ed) Vol 1, Interscience Publishers, New York, USA, 341-356

Swedes JS, Sedo RJ, Atkinson DE (1975) Relation of growth and protein synthesis to the adenylate energy charge in an adenine-requiring mutant of Escherichia coli. J Biol Chem 250, 6930-6938

Ushida K, Jouany JP, Thivend P (1986) Role of rumen protozoa on nitrogen digestion in sheep given two isonitrogenous diets. Br J Nutr 56, 407-419

Ushida K, Kaneko T, Kojima Y (1987) Effect of presence of large entodinionorph protozoa on the rumen bacterial flora, fauna composition of small entodinia and in vitro cellulolysis and xylanalysis. Jpn J Zootech Sci 58, 893-902

Ushida K, Jouany JP, Demeyer DI (1991) Effects of presence or absence of rumen protozoa on the efficiency of utilization of concentrate and fibrous feeds. In: Physiological Aspects of Digestion and Metabolism in Ruminants (T Tsuda, Y Sasaki, R Kawashima, eds), Academic Press, New York, USA, 625-654

Van Eenaeme C, Bienfait JM, Lambot O, Pondant A (1969) Détermination automatique de l'ammoniaque dans le liquide du rumen par la méthode de Berthelot adaptèe à l'autoanalyzeur. An Méd Vét 7, 419-424 
Van Soest PJ, Wine RH (1967) Use of detergents in the analysis of fibrous feeds. Determination of plant cellwall constituents. J Assoc Off Agric Chem 50, 5055

Veira DM (1986) The role of ciliate protozoa in nutrition of the ruminant. J Anim Sci63, 1547- 1560

Veira DM, Ivan M, Jui PY (1984) The effect of ciliate protozoa on the flow of amino acids from the stomach of sheep. Can J Anim Sci64 (suppl) 22-23

Wallace RJ, West AA (1982) Adenosine 5'-triphosphate and adenylate energy charge in sheep digesta. $\checkmark$ Agric Sci Camb 98, 523-528
Warner $\mathrm{ACl}$ (1962) Some factors influencing the rumen microbial population. J Gen Neurobiol 28, 129-146

Whitelaw FG, Eadie JM, Mann SO, Reid RS (1972) Some effects of rumen ciliate protozoa in cattle given restricted amounts of a barley diet. Br J Nutr 27, 425-437

Williams AG, Coleman GS (1992) The Rumen Protozoa. Springer-Verlag, New York, USA, p 441

Wolstrup J, Jensen K (1978) Adenosine triphosphate and deoxyribonucleic acid in the alimentary tract of cattle fed different nitrogen sources. J App/Bact 45 , $49-56$ 